\title{
Implementasi Pelayanan Prima Sebagai Upaya Meningkatkan Marketing Sekolah
}

\author{
Fantika Febry Puspitasari \\ Universitas Islam Negeri Maulana Malik Ibrahim Malang \\ Email: fantika@mpi.uin-malang.ac.id
}

Abstract. Education is a public service institution that aims to educate the nation. In achieving this goal, SDIT Taqiyya Rosyida is committed to dedicate excellent services to achieve the quality of education. The purpose of this research is to know how to implement excellent services as an effort to improve the marketing of schools in SDIT Taqiyya Rosyida. This research uses qualitative methods of descriptive. Data is collected through observation, interviews, and documentation. Research subjects are principals and research informers include teachers, students, employees, and parents. The results of this research are the implementation of excellent services in the form of: 1) Training of Excellence Services, 2) creating friendly communication, 3) animate a family atmosphere, 4) provide quality facilities, where the implementation of excellent services was able to make SDIT Taqiyya Rosyida reached the acceptance of 112 students divided into 4 study groups, in the fifth year.

Keywords. Implementation, Excellence Services, Marketing of School

Abstrak. Pendidikan merupakan lembaga pelayanan publik yang bertujuan untuk mencerdaskan bangsa. Tujuan penelitian ini adalah untuk mengetahui bagaimana implementasi pelayanan prima sebagai upaya meningkatkan marketing sekolah di SDIT Taqiyya Rosyida. Penelitian ini menggunakan metode kualitatif deskriptif. Data dikumpulkan melalui observasi, wawancara, dan dokumentasi. Subjek penelitian adalah kepala sekolah dan informan penelitian meliputi guru, siswa, karyawan, dan wali murid. Hasil penelitian ini adalah implementasi pelayanan prima dalam bentuk: 1) Training khusus pelayanan prima, 2) mewujudkan komunikasi ramah, 3) menghidupkan nuansa kekeluargaan, 4) memberikan fasilitas yang memadai, di mana implementasi pelayanan prima tersebut mampu membuat SDIT Taqiyya Rosyida mencapai penerimaan siswa sebanyak 112 yang terbagi dalam 4 rombongan belajar, pada tahun kelima.

Kata Kunci. Implementasi, Pelayanan Prima, Marketing Sekolah

Copyright (C JMPI: Jurnal Manajemen Pendidikan Islam. All Right Reserved.

This is an open access article under the CC BY-NC-ND license

(http:/ / creativecommons.org/licenses/by-nc-nd/4.0/).

\section{A. PENDAHULUAN}

Salah satu tantangan bangsa pada masa ini adalah memberikan pendidikan yang mencerdaskan bagi warga negaranya sesuai dengan tujuan bangsa Indonesia dalam pembukaan Undang-Undang Dasar 1945. Pendidikan yang sesuai dengan tujuan bangsa hanya mampu terwujud melalui satuan pendidikan yang memiliki kemauan dan kemampuan untuk terus meningkatkan kualitas. Melalui pendidikan berkualitas, relevansi pendidikan dalam mencapai titik perubahan manusia dapat terwujud. Karena sejatinya manusia dididik untuk berubah dari tidak tahu menjadi tahu, dari tidak mengerti menjadi mengerti, sehingga manusia mampu berpikir kritis analitis untuk mencapai peningkatan taraf hidup, agama dan bangsa agar tidak tertinggal (Rosyadi \&

Vol. 4 No. 1, Juni 2019

J-MPI homepage: http://ejournal.uin-malang.ac.id/index.php/jmpi/index 
Pardjono, 2015).

Satuan pendidikan merupakan lembaga pelayanan publik yang bertujuan untuk memanusiakan manusia. Sehingga dalam praktiknya, satuan pendidikan tidak beroerientasi pada materi komersil, melainkan lebih pada pelayanan terhadap masyarakat. Imanuel Kant menyatakan bahwa manusia baru menjadi manusia sejati karena pendidikan. Artinya, pendidikan merupakan hal substantif dalam membangun peradaban manusia (Idris \& Za, 2017). Realitas bahwa pendidikan bersifat humanis, menjadi salah satu faktor pentingnya mewujudkan pelayanan yang optimal dalam dunia pendidikan. Menurut Gouthier, munculnya globalisasi dan ketatnya persaingan menuntut setiap organisasi untuk mencapai pelayanan yang sempurna (Sekhon et al., 2015).

Menurut Prasetyawati (dalam Putra, 2019) pelayanan prima adalah upaya maksimal terbaik yang diberikan sehingga dapat memenuhi kebutuhan sesuai keinginan pengguna jasa. Karena sesungguhnya inti dari pelayanan prima adalah kepuasan pelanggan. Permasalahan kualitas pelayanan merupakan salah satu penghambat dalam memasuki dunia persaingan, melihat kondisi sekolah-sekolah yang makin kompetitif. Persaingan dalam dunia pendidikan saat ini sangat ketat. Setiap lembaga berlombalomba untuk menampilkan prestasi dan keunggulannya, terutama nampak pada sekolah-sekolah swasta. Fenomena ini menjadi cambuk bagi sekolah negeri untuk tetap mempertahankan daya saing. Banyak cara ditempuh guna meningkatkan daya saing. Meningkatkan kompetensi pedagogik pendidik, berusaha menambah daftar prestasi, hingga meningkatkan kualitas pelayanan umum. Upaya tersebut dimaksudkan untuk mencapai titik loyalitas masyarakat pengguna jasa pendidikan sebuah lembaga (Aryani \& Rosinta, 2011). Pelayanan prima menjadi salah satu daya tarik bagi masyarakat. Menurut Utami (2011) kepuasan masyarakat tercapai ketika ekspektasi berbanding lurus dengan apa yang mereka peroleh, dalam hal ini kualitas dan pelayanan.

Pelayanan prima dilaksanakan demi mencapai kepuasan pelanggan bahkan menjadi perhatian penting dalam pemerintah daerah di Amerika Serikat (Abdelkader Benmansour, 2018). Hal ini membuktikan bahwa pelayanan memiliki peran penting dalam sebuah sistem yang dijalankan berkaitan dengan kualitas, baik kualitas hidup maupun kualitas produk. Semakin tinggi kualitas pelayanan, maka semakin rendah tingkat kekhawatiran pelanggan terhadap pelayanan sebuah instansi(Simamora et al., 2019). Dalam kasus pendidikan, Semakin tinggi tingkat kualitas pelayanan, semakin rendah pula keraguan masyarakat dalam memutuskan memilih sekolah tersebut. Artinya masyarakat memiliki keyakinan yang tinggi untuk memilih sekolah yang dituju.

Selama ini, pelayanan prima menjadi salah satu prinsip utama yang dipegang oleh perusahaan komersil dalam menjaga kualitas dan kerjasama. Ketika memasuki sebuah dealer mobil, konsumen akan disambut dengan keramah tamahan customer service. Terdapat Standar operasional khusus tentang bagaimana cara menyapa konsumen hingga menawarkan pelayanan yang mampu membuat konsumen merasa senang dan nyaman. Sedangkan dalam dunia pendidikan, konsep ini justru sering terlupakan. Lemahnya komunikasi yang dibangun antara sekolah dengan masyarakat, sekolah dengan komite, tenaga pendidik dengan orang tua, menjadi salah satu penyebab masalah yang seringkali muncul. Sedangkan sesungguhnya masyarakat merupakan pemasar terbaik yang dimiliki oleh sekolah.

Kepercayaan masyarakat serta warga internal sekolah dibangun di atas rasa

Vol. 4 No. 1, Juni Tahun 2019

J-MPI homepage: http://ejournal.uin-malang.ac.id/index.php/jmpi/index 
nyaman dan puas terhadap pelayanan dalam sebuah satuan pendidikan. Kemampuan satuan pendidikan dalam melayani masyarakat serta warganya mampu menjadi salah satu indikator kualitas sumber daya manusia di dalamnya. Pelayanan prima oleh sumber daya manusia dalam satuan pendidikan memiliki peran dalam meningkatkan rasa nyaman dan kepuasan masyarakat. Dalam literatur manajemen layanan, para konsumen termasuk dalam dunia pendidikan sangat menghargai pelayanan yang baik. Bahkan beberapa penelitian telah mengaitkan adanya hubungan antara kepuasan pelanggan, loyalitas, dan keuntungan (Bates, Bates, \& Johnston, 2003). Artinya dengan memberikan pelayanan yang maksimal, masyarakat akan merasa puas dan percaya pada satuan pendidikan. Masyarakat akan turut serta memasarkan sekolah melalui penyampaian keunggulan sekolah sehingga pasar semakin luas. Kepuasan masyarakat terhadap sekolah menjadi salah satu prestasi yang melegakan. Sebagai sebuah usaha penyedia jasa layanan publik, mampu memberikan pelayanan yang optimal, memuaskan, dan sesuai dengan harapan masyarakat menjadi sebuah capaian prestasi (Marlina, 2016)

SDIT Taqiyya Rosyida, merupakan sekolah yang sangat menyadari pentingnya pelayanan prima dalam meningkatkan mutu layanan sekolah. Pemikiran ini dibawa oleh Arif Priyanto, seorang anggota yayasan bidang pendidikan. Pemikiran beliau untuk memberikan pelayanan yang optimal pada masyarakat dan pengguna jasa menjiwai semangat warga sekolah untuk turut mensukseskan konsep tersebut sebagai upaya meningkatkan mutu dan marketing sekolah. Pelayanan prima tak hanya diberikan pada masyarakat, namun juga pada warga internal sekolah sehingga prestasinya terus meningkat. Sekolah yang baru 6 tahun berdiri ini, berhasil meluluskan pada angkatan pertama dengan peringkat 9 dari 60 sekolah. Sekolah ini juga telah mengantongi berbagai juara perlombaan baik akademik maupun non-akademik, di antaranya kejuaraan MAPSI dan beberapa kejuaraan di bidang olahraga. Tren pendaftaran peserta didik pun semakin meningkat setiap tahunnya.

\section{B. METODE}

Penelitian ini merupakan penelitian kualitatif deskriptif mengenai implementasi pelayanan prima sebagai upaya meningkatkan marketing sekolah di SDIT Taqiyya Rosyida. Pengumpulan data dilakukan melalui proses observasi, wawancara, dan dokumentasi terhadap aktivitas yang berkaitan dengan pelayanan prima di SDIT Taqiyya Rosyida. Subjek penelitian adalah kepala sekolah dan informan penelitian meliputi guru, siswa, karyawan, dan wali murid. Teknik analisis data dilakukan melalui reduksi data, pemaparan data, dan penarikan kesimpulan. Reduksi data dilakukan dengan memilah informasi-informasi penting yang berkaitan dengan pelayanan prima di SDIT Taqiyya Rosyida. Pemaparan data dilakukan dengan menyajikan informasi terkait impelemntasi pelayanan prima di SDIT Taqiyya Rosyida sehingga mudah untuk dipahami bagaimana pelaksanaannya. Penarikan kesimpulan dilakukan dengan mencari makna penting dari informasi tentang implementasi pelayanan prima sebagai upaya meningkatkan marketing sekolah. Teknik keabsahan data menggunakan triangulasi sumber yaitu mengajukan pertanyaan yang sama tentang implementasi pelayanan prima di SDIT Taqiyya Rosyida kepada kepala sekolah, guru, siswa, karyawan, dan wali murid. Triangulasi teknik yaitu dengan mengecek keabsahan data melalui sinkronisasi hasil wawancara, observasi, dan dokumentasi.

Vol. 4 No. 1, Juni 2019

J-MPI homepage: http://ejournal.uin-malang.ac.id/index.php/jmpi/index 


\section{HASIL DAN PEMBAHASAN}

Berdasarkan penelitian yang dilakukan, data menunjukkan bahwa dalam meningkatkan marketing sekolah melalui pelayanan prima SDIT Taqiyya Rosyida memformulasikan 4 konsep yang diimplementasikan oleh seluruh warga sekolah.

Gambar 1 Implementasi Pelayanan Prima di SDIT Taqiyya Rosyida

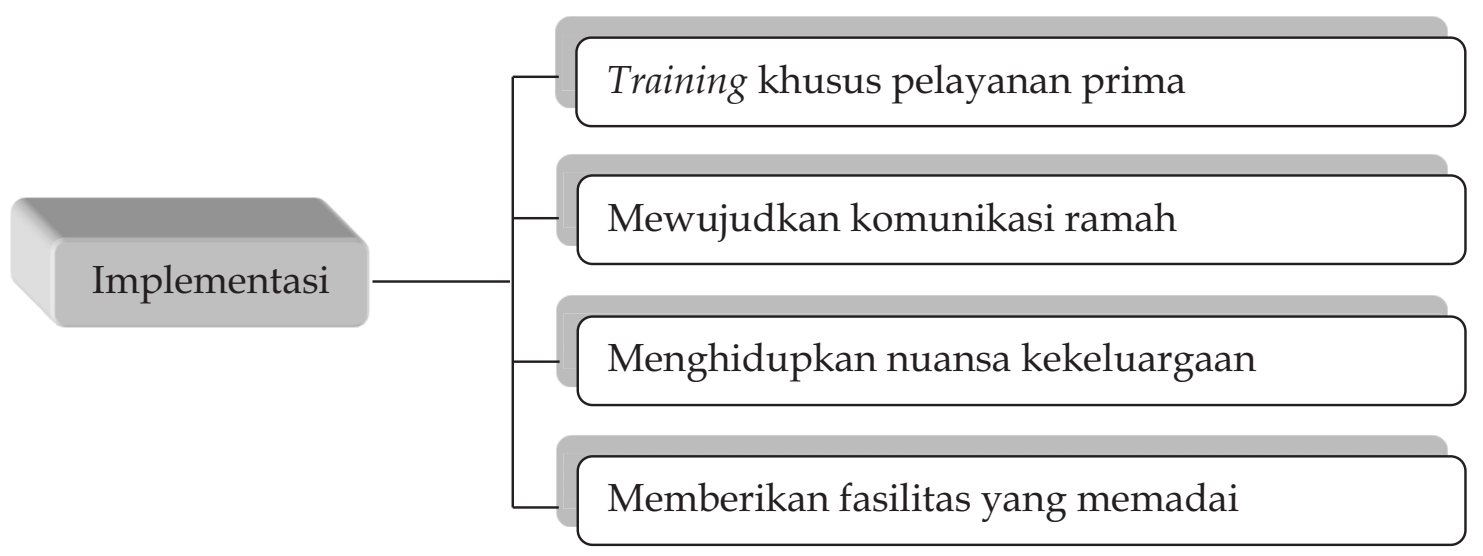

SDIT Taqiyya Rosyida berkomitmen dalam memberikan pelayanan prima terhadap masyarakat. Tidak saja masyarakat sekitar, namun juga masyarakat sekolah itu sendiri. Menurut kepala SDIT Taqiyya Rosyida, sekolah yang maju adalah sekolah yang mampu memberikan pelayanan yang optimal, di mana ketika berhubungan dengan sumber daya manusia di dalamnya, siapa pun akan merasa puas dan senang.

Pelayanan prima di SDIT Taqiyya Rosyida diimplementasikan dalam bentuk: Training khusus pelayanan prima

Sekolah memiliki jadwal rutin dalam melakukan upgrade sumber daya manusia. Setiap hari sabtu, dilaksanakan berbagai macam pelatihan untuk guru dan karyawan, salah satunya training tentang pelayanan prima. Agenda tersebut di bawah tanggung jawab yayasan bidang pendidikan. Melalui pelatihan pelayanan prima, penyedia layanan jasa mampu mengevaluasi kelebihan dan kekurangan yang dimiliki dalam melakukan pelayanan (Simamora, 2018). Training pelayanan prima yang dilaksanakan setiap tahun di SDIT Taqiyya Rosyida mampu menjadi sarana berbenah seluruh tenaga pendidik dan kependidikan. Mereka mampu menganalisis potensi yang dapat dikembangkan dengan modal karakteristik sumber daya manusia yang ada, serta melakukan evaluasi terhadap kekurangan untuk melakukan perbaikan.

Training pelayanan prima memberikan bekal kepada guru dan karyawan bagaimana cara menerima tamu dengan baik, memberikan senyum pada setiap orang yang ditemui baik orang luar maupun orang dalam termasuk pada sesama rekan kerja hingga penjaga sekolah, dan senantiasan bersikap ramah pada siswa. Pelatihan rutin yang dilaksanakan setiap sabtu merupakan wujud dalam meningkatkan kapabilitas guru dan karyawan dalam menyelenggarakan lembaga pendidikan. Upaya ini juga merupakan langkah yang ditempuh untuk memberikan pelayanan prima. Sekolah berupaya menyediakan tenaga pendidik dan kependidikan yang profesional dan kapabel di bidangnya melalui peningkatan skill yang berkelanjutan.

Pelatihan pelayanan prima bertujuan untuk memahamkan konsep pelayanan

Vol. 4 No. 1, Juni Tahun 2019

J-MPI homepage: http://ejournal.uin-malang.ac.id/index.php/jmpi/index 
pada seluruh anggota instansi. Penyedia jasa dilatih untuk memahami dari sudut pandang pengguna jasa dan memahami 9 poin pelayanan yaitu: kemudahan akses, tanggung jawab, kompetensi, sopan santun, tingkat kepercayaan, kecepatan layanan, keamanan, transparan, dan professional. Penyedia jasa mampu memahami komunikasi efektif demi menciptakan image yang menarik bagi pengguna jasa. Melatih setiap anggota untuk memahami karakteristik pengguna jasa sehingga mampu menyampaikan pesan dengan baik sehingga memunculkan loyalitas pengguna jasa (Rahma, 2010). Dengan begitu, tenaga pendidik dan kependidikan mampu melayani masyarakat, terutama siswa dan wali murid dengan pelayanan yang tepat dan memuaskan.

Mewujudkan komunikasi ramah

Berdasar pada Rahma (2010), salah satu poin pelayanan prima adalah sopan santun. Maka warga sekolah dibiasakan terus-menerus hingga mampu membudayakan pola komunikasi yang sopan dan ramah pada setiap orang. Hal ini dimulai dari komunikasi kepala sekolah pada guru dan karyawan yang lebih demokratis dan santun, tidak terkesan otoriter dan keras. Hal demikian juga dipraktikkan oleh guru pada para siswa. Guru terbiasa bersikap ramah pada siswa sehingga membuat siswa segan dan turut bersikap sopan. Komunikasi yang ramah juga dirasakan wali murid. Wali murid memperoleh sambutan hangat setiap mengantar dan menjemput anak sekolah. Guru piket dengan ramah dan hangat menyambut para wali murid di depan gerbang.

Dalam menerima komplain dari wali murid atau masyarakat, sekolah membiasakan guru dan karyawan untuk tetap menanggapi dengan sopan, tidak memberikan jawaban disertai emosi, dan berusaha meredam suasana. Profesionalitas untuk segera meneruskan laporan pada jalur yang tepat, dibiasakan untuk memberikan feedback yang memuaskan atas komplain yang ditujukan ke sekolah.

Menghidupkan nuansa kekeluargaan

Sekolah berusaha menjadikan seluruh warga sekolah, wali murid dan masyarakat sekitar sebagai keluarga besar sekolah. Dalam memberikan pelayanan, sebuah lembaga pelayanan publik dalam hal ini sekolah, melibatkan dan memberikan perhatian khusus pada masyarakat, terutama siswa dan wali murid menjadi sesuatu yang bernilai melebihi formalitas penyelenggaraan pendidikan (Padma \& Wagenseil, 2018). Maka sudah menjadi sebuah keharusan bagi pendidikan untuk memberikan porsi perhatian yang lebih terhadap hubungan sosial dengan masyarakat terutama wali murid. Hal ini diwujudkan dalam bentuk kepedulian sekolah terhadap setiap pihak yang membutuhkan bantuan. Secara system, sekolah memiliki dana sosial. Setiap guru, karyawan, siswa, wali murid, atau masyarakat sekitar tertimpa musibah, sekolah akan memberikan kepedulian dalam bentuk simpati serta materi.

Selain wujud kepedulian, sekolah juga memfasilitasi silaturahim antar wali murid yang terdapat dalam program POMG (Pertemuan Orang tua Murid dan Guru). Kegiatan ini dilaksanakan rutin sebulan sekali sebagai media silaturahim antara sekolah dengan wali murid. Melalui program ini, guru lebih dekat dengan wali murid dan wali murid dapat saling mengenal dan dekat satu sama lain. Diskusi demi kebaikan anak dapat terwujud melalui program tersebut. Program POMG (Pertemuan Orang tua Murid dan Guru) merupakan salah satu program yang juga dimaksudkan untuk menyampaikan setiap informasi penting sekolah. Informasi ini dapat berkaitan dengan kegiatan sekolah, juga tentang kondisi perkembangan siswa di sekolah. Wali murid tidak hanya menerima informasi formal terkait system dan program, melainkan juga mengetahui permasalahan

Vol. 4 No. 1, Juni 2019

J-MPI homepage: http://ejournal.uin-malang.ac.id/index.php/jmpi/index 
dan perkembangan anak mereka. Grup whatsapp dibuat per kelas dan setiap guru yang bertanggung jawab wajib melayani keluh kesah, pertanyaan dan masukan dari wali murid dengan baik.

Memberikan fasilitas yang memadai

Menurut Klavert (2015) Penyediaan gedung dan kualitas sumber daya manusia merupakan hal yang dipertimbangkan dalam memberikan pelayanan. Pada tahun keempat, sekolah mulai membangun gedung sebagai wujud dalam memberikan fasilitas yang layak. Fasilitas dibangun dengan konsep memberikan rasa nyaman bagi warga sekolah maupun wali murid dan tamu yang berkunjung. Membangun area jemputan yang teduh dan memiliki tempat duduk, membangun kanopi untuk melindungi dari panas dan hujan, membangun kolam renang, merupakan beberapa teknis yang telah direalisasikan untuk memberikan pelayanan prima. Pelayanan prima tidak hanya dilaksanakan oleh warga sekolah, melainkan juga yayasan sekolah. Andil pengurus yayasan dalam mendukung terealisasinya program-program sekolah, menjadi wujud kepedulian yayasan terhadap konsep pelayanan prima.

Hasil penelitian di sebuah rumah sakit, menunjukkan bahwa semakin tinggi kepuasan pasien rawat inap terhadap pelayanan perawatan, maka semakin rendah tingkat kecemasannya terhadap suatu layanan (Suherni, 2014). Upaya mengimplementasikan pelayanan prima tersebut memberikan kepuasan terutama sangat nampak dari wali murid. Wali murid merasa nyaman dengan pelayanan dan komunikasi sekolah, sehingga wali murid tidak ragu untuk menyebarluaskan keunggulan dan prestasi sekolah untuk turut memasarkan. Bahkan beberapa wali murid berani membela dan menjaga nama baik sekolah ketika terdengar berita kurang baik dari luar. Hasilnya nampak pada penerimaan peserta didik tahun ajaran 2018/2019, tepatnya pada tahun kelima SDIT Taqiyya Rosyida berhasil menjaring dua kali lipat peserta didik baru sejumlah 112 siswa melalui seleksi dan terbagi ke dalam 4 rombongan belajar walau belum pernah meluluskan sama sekali.

\section{KESIMPULAN}

Hasil penelitian ini, implementasi pelayanan prima dalam bentuk: 1) training khusus pelayanan prima, 2) mewujudkan komunikasi ramah, 3) menghidupkan nuansa kekeluargaan, 4) memberikan fasilitas yang memadai. Pelaksanaan konsep pelayanan prima tersebut, mampu meningkatkan marketing sekolah, terbukti dengan meningkatnya penerimaan siswa baru sebesar dua kali lipat yaitu 112 siswa yang terbagi dalam 4 rombongan belajar. Ke depan, akan lebih baik lagi jika sekolah membuat angket untuk wali murid dan siswa terkait kepuasan terhadap pelayanan sekolah, sehingga sekolah memperoleh data valid sebagai bahan evaluasi dan perbaikan.

\section{REFERENSI}

Abdelkader Benmansour, N. (2018). Citizens and expatriates satisfaction with public services in Qatar - evidence from a survey. International Journal of Social Economics, 46(3), 326-337. https:/ / doi.org/10.1108/IJSE-03-2018-0118

Aryani, D., \& Rosinta, F. (2011). Pengaruh kualitas layanan terhadap kepuasan pelanggan dalam membentuk loyalitas pelanggan. Bisnis \& Birokrasi Journal, 17(2).

Vol. 4 No. 1, Juni Tahun 2019

J-MPI homepage: http://ejournal.uin-malang.ac.id/index.php/jmpi/index 
Bates, K., Bates, H., \& Johnston, R. (2003). Linking service to profit: The business case for service excellence. International Journal of Service Industry Management, 14(2), 173183.

Idris, S., \& Za, T. (2017). Realitas Konsep Pendidikan Humanisme Dalam Konteks Pendidikan Islam. Jurnal EDUKASI: Jurnal Bimbingan Konseling, 3(1), 96. https://doi.org/10.22373/je.v3i1.1420

Klavert, Lorry Priska. (2015). Pengaruh Kualitas Pelayanan Terhadap Kepuasan Nasabah Pada Pt. Bank Rakyat Indonesia (Persero) Tbk. Unit Politeknik. Politeknik Negeri Manado Jurusan Administrasi Bisnis Program Studi Manajemen Bisnis, 15-17.

Marlina, L. (2016). Evaluasi Kualitas Pelayanan Proses Pembelajaran Di Prodi Manajemen Pendidikan Islam Fakultas Tarbiyah Dan Keguruan Uin Raden Fatah Palembang. 1(2), 14.

Padma, P., \& Wagenseil, U. (2018). Retail service excellence: Antecedents and consequences. International Journal of Retail E Distribution Management, 46(5), 422 441. https:// doi.org/10.1108/IJRDM-09-2017-0189

Putra, A. M. (2019). Pelaksanaan Pelayanan Prima Terhadap Kepercayaan Nasabah Di PT. Bank Perkreditan Rakyat Jorong Kampung Tangah Pariaman.

Rahma. Y. N. (2010). Manajemen Pelayanan Prima.Yogyakarta: Graha Ilmu

Rosyadi, Y. I., \& Pardjono, P. (2015). Peran Kepala Sekolah Sebagai Manajer Dalam Meningkatkan Mutu Pendidikan di SMP 1 Cilawu Garut. Jurnal Akuntabilitas Manajemen Pendidikan, 3(1), 124-133.

Sekhon, H. S., Al-Eisawi, D., Roy, S. K., \& Pritchard, A. (2015). Service excellence in UK retail banking: Customers' perspectives of the important antecedents. International Journal of Bank Marketing, 33(7), 904-921. https://doi.org/10.1108/IJBM-10-20140136

Simamora, R.H. (2018). Buku Ajar: Keselamatan Pasien Melalui Timbang Terima Pasien berbasis Komunikasi Efektif. Usu Press

Simamora, R. H., Purba, J. M., Bukit, E. K., \& Nurbaiti, N. (2019). Penguatan Peran Perawat Dalam Pelaksanaan Asuhan Keperawatan Melalui Pelatihan Layanan Prima. JPPM (Jurnal Pengabdian Dan Pemberdayaan Masyarakat), 3(1), 25-31.

Suherni. (2014). Hubungan Kualitas Pelayanan Prima Perawat dengan Loyalitas Pasien di RSUD Dr. Pirngadi. Thesis. Magister Keperawatan F.Kep USU. Repositori USU

Utami, S. F. (2011). Penerapan Pelayanan Prima Kepada Nasabah di Perusahaan Daerah Bank Perkreditan Rakyat (Bpr) Sarimadu Bangkinang. Laporan akhir. Pekanbaru: Fakultas Syari'ah Dan Ilmu Hukum Universitas Islam Negeri Sultan Syarif Kasim.

Vol. 4 No. 1, Juni 2019

J-MPI homepage: http://ejournal.uin-malang.ac.id/index.php/jmpi/index 